\title{
Spawning, larval abundance and growth rate of Sardinops sagax off southwestern Australia: influence of an anomalous eastern boundary current
}

\author{
B. A. Muhling ${ }^{1}$, L. E. Beckley ${ }^{1, *}$, D. J. Gaughan ${ }^{2}$, C. M. Jones ${ }^{1}$, A. G. Miskiewicz ${ }^{3}$, \\ S. A. Hesp ${ }^{4}$ \\ ${ }^{1}$ School of Environmental Science, and ${ }^{4}$ School of Biological Sciences, Murdoch University, 90 South St, Murdoch 6150 , \\ Western Australia, Australia \\ ${ }^{2}$ Department of Fisheries, Western Australia, PO Box 20, North Beach 6920, Western Australia, Australia \\ ${ }^{3}$ Environment and Health Division, Wollongong City Council, 41 Burelli Street, Wollongong 2500, New South Wales, Australia
}

\begin{abstract}
The temporal and spatial distributions of sardine Sardinops sagax eggs and larvae off the oligotrophic southwestern coast of Australia were examined and related to gonadosomatic index, daily growth rates of larvae and regional biological oceanography. Seasonal environmental cycles were established from remotely sensed sea surface temperature and chlorophyll concentration, wind and sea surface height data. Sardine egg and larval distributions were determined from regular transect surveys and annual grid surveys. Sardine eggs and larvae were common across the continental shelf throughout the year between Two Rocks and Cape Naturaliste ( 32 to $\left.34^{\circ} \mathrm{S}\right)$, and gonadosomatic index data suggested a distinct winter peak in spawning activity. Surface chlorophyll concentrations were highest during winter, coincident with the seasonal peak in the southward flow of the Leeuwin Current along the continental shelf break. Retention conditions on the mid-outer shelf for pelagic eggs and larvae were therefore poor during this time. Egg and larval concentrations were lower than expected in winter and higher in summer when retention conditions were more favourable. Larval sardine growth rates were unexpectedly high, averaging $0.82 \mathrm{~mm} \mathrm{~d}^{-1}$. Fisheries for clupeiod species off southwestern Australia are insignificant compared to other eastern boundary current systems. Our data suggest that this may be due to a combination of low primary productivity caused by suppression of large-scale upwelling by the Leeuwin Current and the modest seasonal maximum in primary productivity occurring during the time least favourable for pelagic larval retention.
\end{abstract}

KEY WORDS: Biological oceanography $\cdot$ Sardinops sagax $\cdot$ Leeuwin Current $\cdot$ Fish larvae $\cdot$ Fish eggs

\section{INTRODUCTION}

Small pelagic clupeiform fishes such as sardine Sardinops sagax and anchovies Engraulis spp. are ubiquitous in cool to warm temperate coastal oceans worldwide, and are particularly abundant in eastern boundary current systems. They are an important component of many marine food webs, and they support substantial fisheries (Beckley \& van der Lingen 1999). However, recruitment is often highly variable from year to year, resulting in large fluctuations in stock sizes and catches (Beckley \& van der Lingen 1999, Schwartzlose et al. 1999, Smith \& Moser 2003).

The sardine is generally found in upwelling areas, with the highest catches recorded off California, Peru and southern Africa (Beckley \& van der Lingen 1999). Much of the variability in adult population sizes and spawning biomass of this species has been linked to climatic and environmental variables (Beckley \& van der Lingen 1999, Schwartzlose et al. 1999). For 
example, the stock size of sardine in the California Current region decreased substantially from the 1940s to the 1970 s, followed by a rapid recovery in the 1980s. Although this was partially related to fishing pressure, a major environmental change in the northeastern Pacific in the 1970s (from a 'cool-ocean' to a 'warmocean' oceanographic regime) resulted in marked changes in abundance of a number of fish species, including sardine (Smith \& Moser 2003). The El Niño phenomenon has also been implicated in changes in sardine stock sizes in the Gulf of California (SanchezVelasco et al. 2004) and off Mexico (Funes-Rodriguez et al. 2001). In the Benguela Current ecosystem off southern Africa, sardine recruitment has been linked to variability in sea surface temperature (which approximates upwelling events), larval fish retention, and fishing pressure (Cole 1999).

Variability in recruitment to adult sardine populations has been attributed to varying rates of survival in early life history stages (Smith \& Moser 2003). Different environmental conditions result in different retention, transport and feeding conditions for pelagic fish larvae, with subsequent effects on recruitment (Lasker \& Smith 1976, Smith \& Moser 2003). Sardines typically spawn in continental shelf waters, and have protracted spawning seasons (Beckley \& van der Lingen 1999, Smith \& Moser 2003). The timing of spawning may differ between geographical regions (Ward et al. 2003) and be influenced by local environmental conditions, with maximum spawning activity occurring when deleterious offshore transport is at a minimum and larval fish food concentrations are favourable (Somarakis et al. 2006). Concentrations of sardine eggs and larvae at the same location and season may therefore vary considerably among years (Fletcher et al. 1994, Gaughan et al. 2001a, Smith \& Moser 2003).
Sardines occur in the eastern Indian Ocean from inshore to outer continental shelf waters south of Shark Bay, Western Australia (Hutchins \& Thompson 2001) (Fig. 1). However, stock sizes and commercial catches of this species are insignificant by world standards, with the annual catch yet to reach $20000 \mathrm{t}$ (Caputi et al. 1996, Gaughan et al. 2001a). This is largely attributable to the lower productivity of southwestern Australian coastal waters, a product of the downwelling, poleward-flowing Leeuwin Current (Feng et al. 2003, Hanson et al. 2005). Leeuwin Current flow results in southward penetration of warm, low salinity waters, and the current is strongly seasonal, with maximum flows in autumn and winter (Pearce et al. 2006). In contrast to the wind-induced upwelling, and consequent increases in nutrients and chlorophyll biomass that are characteristic of other eastern boundary current systems (Thomas et al. 2004), there is no large-scale upwelling associated with the Leeuwin Current. Chlorophyll biomass off southwestern Australia is, instead, at a maximum in winter when equatorward wind stress is at a minimum (Hanson et al. 2005, Pearce et al. 2006, Fearns et al. 2007). This modest seasonal chlorophyll maximum likely results from winter deepening of the mixed layer, nutrient re-suspension, terrestrial inputs near shore (Lourey et al. 2006) and possibly some southward entrainment of nutrients and chlorophyll (Hanson et al. 2005).

Larval fishes feeding in southwestern Australian neritic waters are therefore expected to grow at slower rates than those in more productive systems in other eastern boundary currents (Gaughan et al. 2001b), with implications for larval fish starvation, and mortality through predation (Bailey \& Houde 1989). However, the relationships between larval sardines and their physical and biological environment have not been well studied

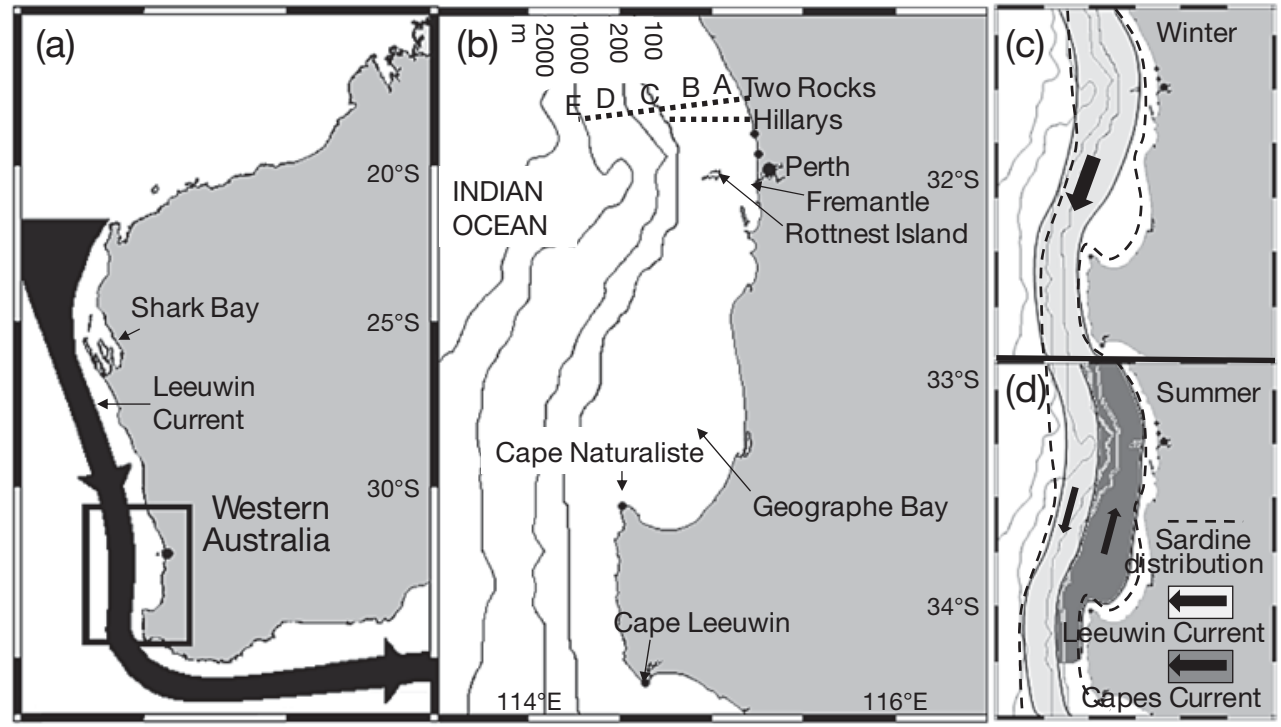

Fig. 1. Study area off southwestern Australia showing (a) the overall path of the Leeuwin Current, (b) locations of the Two Rocks transect with stations, the Hillarys transect and places mentioned in the text, (c) the winter and (d) the summer variation in location of the Leeuwin Current. Known distribution of adult sardines is also indicated 
off Western Australia, with the exception of some work completed along the south coast, east of Albany (approximately 34 to $35^{\circ} \mathrm{S}$, and 118 to $122^{\circ} \mathrm{E}$ ) (Fletcher \& Tregonning 1992, Gaughan et al. 2001a,b).

Our aim was to collate a variety of existing data sets to determine the sardine spawning season, and temporal and spatial distributions of sardine eggs and larvae off the southwestern coast of Australia, and relate these to regional biophysical oceanography. We hypothesised that maximum abundances of sardine larvae would occur after periods of high spawning activity (as shown by gonadosomatic index and egg concentration data), and periods when both feeding and retention conditions were favourable.

\section{MATERIALS AND METHODS}

Study area. This study synthesised a number of data sets (Table 1) collected on a range of temporal and spatial scales off southwestern Australia between Two Rocks (31 $35^{\prime} \mathrm{S}$ ) and Cape Leeuwin (34⒉ $22^{\prime} \mathrm{S}$ ) between 1997 and 2004 (Fig. 1).
Environmental variables. Mean monthly ocean colour (surface chlorophyll) data were acquired for the study area using the GES-DISC Interactive Online Visualization ANd aNalysis Infrastructure (Giovanni). Although a deep chlorophyll maximum layer may be present in our study area in summer, remotely sensed data were considered to adequately illustrate the regional, seasonal cycle of chlorophyll throughout the water column. Integrated chlorophyll through the water column is still much lower in summer than in winter, and the seasonal cycle for depth-integrated chlorophyll is similar to that for surface chlorophyll data (Koslow et al. 2006, Fearns et al. 2007).

The Two Rocks transect was $84 \mathrm{~km} \mathrm{long,} \mathrm{and}$ comprised 5 sampling stations, representing coastal (A: $18 \mathrm{~m}$ depth, $31^{\circ} 32.2^{\prime} \mathrm{S}, 115^{\circ} 33.6^{\prime} \mathrm{E}$ ), inner shelf (B: $\left.40 \mathrm{~m}, 31^{\circ} 37.1^{\prime} \mathrm{S}, 115^{\circ} 21.9^{\prime} \mathrm{E}\right)$, outer shelf (C: $100 \mathrm{~m}$, $31^{\circ} 40.8^{\prime} \mathrm{S}, 115^{\circ} 13.3^{\prime} \mathrm{E}$ ), shelf break (D: $300 \mathrm{~m}$, $\left.31^{\circ} 45.9^{\prime} \mathrm{S}, 115^{\circ} 01.2^{\prime} \mathrm{E}\right)$, and offshore environments (E: $\left.1000 \mathrm{~m} 31^{\circ} 51.7^{\prime} \mathrm{S}, 114^{\circ} 47.6^{\prime} \mathrm{E}\right)$. Sea surface temperatures along the Two Rocks transect were extracted from brightness temperatures in AVHRR bands 4 and 5 from satellite images obtained by the Western Aus-

Table 1. Temporal and spatial scales of data sets analysed. DFWA: Department of Fisheries, Western Australia. GES-DISC: Goddard Earth Sciences Data and Information Services Centre

\begin{tabular}{|c|c|c|c|}
\hline Variable & Data source & Study area & Time period \\
\hline \multicolumn{4}{|l|}{ Environmental } \\
\hline Ocean colour & Giovanni (GES-DISC) & $\begin{array}{l}31^{\circ} 35^{\prime} \mathrm{S}-34^{\circ} 14^{\prime} \mathrm{S} \\
114^{\circ} 30^{\prime} \mathrm{E}-116^{\circ} 00^{\prime} \mathrm{E}\end{array}$ & Jan 1998-Dec 2004 \\
\hline Sea surface temperature & $\begin{array}{l}\text { (a) Giovanni (GES-DISC) } \\
\text { (b) AVHRR bands } 4-5\end{array}$ & $\begin{array}{l}\text { (a) } 31^{\circ} 00^{\prime} \mathrm{S}-34^{\circ} 00^{\prime} \mathrm{S}, \\
114^{\circ} 00^{\prime} \mathrm{E}-116^{\circ} 00^{\prime} \mathrm{E} \\
\text { (b) Two Rocks transect: } \\
31^{\circ} 32^{\prime} \mathrm{S}-31^{\circ} 52^{\prime} \mathrm{S}, \\
114^{\circ} 48^{\prime} \mathrm{E}-115^{\circ} 34^{\prime} \mathrm{E}\end{array}$ & Jan 2002-Dec 2004 \\
\hline Fremantle Mean Sea Level & National Tidal Centre & $\begin{array}{l}\text { Fremantle: } \\
32^{\circ} 04^{\prime} \mathrm{S}, 115^{\circ} 44^{\prime} \mathrm{E}\end{array}$ & Jan 1998-Dec 2004 \\
\hline Wind & Australian Bureau of Meteorology & $\begin{array}{l}\text { Rottnest Island: } \\
32^{\circ} 00^{\prime} \mathrm{S}, 115^{\circ} 30^{\prime} \mathrm{E}\end{array}$ & Jan 2000-Dec 2004 \\
\hline \multicolumn{4}{|l|}{ Sardine spawning } \\
\hline Gonadosomatic index (GSI) & $\begin{array}{l}\text { DFWA survey: Fremantle } \\
\text { sardine fishery }\end{array}$ & $\begin{array}{l}31^{\circ} 00^{\prime} \mathrm{S}-33^{\circ} 00^{\prime} \mathrm{S} \\
\sim 115^{\circ} 30^{\prime} \mathrm{E}-115^{\circ} 40^{\prime} \mathrm{E}\end{array}$ & Jan 2000-Dec 2005 \\
\hline \multirow[t]{2}{*}{ Sardine eggs } & DFWA grid & $\begin{array}{l}31^{\circ} 32^{\prime} \mathrm{S}-34^{\circ} 22^{\prime} \mathrm{S} \\
114^{\circ} 30^{\prime} \mathrm{E}-115^{\circ} 40^{\prime} \mathrm{E}\end{array}$ & Aug 2002, Jul 2004 \\
\hline & Hillarys transect & $\begin{array}{l}31^{\circ} 50^{\prime} \mathrm{S} \\
115^{\circ} 19^{\prime} \mathrm{E}-115^{\circ} 44^{\prime} \mathrm{E}\end{array}$ & Jan 1997-Dec 1998 \\
\hline \multirow[t]{3}{*}{$\begin{array}{l}\text { Sardine larvae } \\
\text { Sardine larvae }\end{array}$} & DFWA grid & $\begin{array}{l}31^{\circ} 32^{\prime} \mathrm{S}-34^{\circ} 22^{\prime} \mathrm{S} \\
114^{\circ} 30^{\prime} \mathrm{E}-115^{\circ} 40^{\prime} \mathrm{E}\end{array}$ & Aug 2002, Jul 2004 \\
\hline & Hillarys transect & $\begin{array}{l}31^{\circ} 50^{\prime} \mathrm{S} \\
115^{\circ} 19^{\prime} \mathrm{E}-115^{\circ} 44^{\prime} \mathrm{E}\end{array}$ & Jan 1997-Dec 1998 \\
\hline & Two Rocks transect & $\begin{array}{l}31^{\circ} 32^{\prime} \mathrm{S}-31^{\circ} 52^{\prime} \mathrm{S} \\
114^{\circ} 48^{\prime} \mathrm{E}-115^{\circ} 34^{\prime} \mathrm{E}\end{array}$ & Aug 2002-Dec 2004 \\
\hline Sardine larval growth & Two Rocks transect & $\begin{array}{l}31^{\circ} 32^{\prime} \mathrm{S}-31^{\circ} 52^{\prime} \mathrm{S} \\
114^{\circ} 48^{\prime} \mathrm{E}-115^{\circ} 34^{\prime} \mathrm{E}\end{array}$ & Aug 2002-Dec 2004 \\
\hline
\end{tabular}


tralian Satellite Technology and Applications Consortium (WASTAC) (see Pearce et al. 2006). Monthly mean temperatures for the broader study area were obtained from Giovanni (Table 1).

Fremantle mean sea level (FMSL) data provided a proxy for the strength of the Leeuwin Current (Feng et al. 2003), and data were obtained from 1998 to 2004. Wind data were obtained from an Automatic Weather Station (AWS) operated by the Australian Bureau of Meteorology at Rottnest Island (Fig. 1).

Sardine spawning indices. The gonadosomatic index (GSI) (ratio of ovary weight to body weight, DeVlamming et al. 1982) was used to calculate the sardine spawning period. Data were collected from 2730 adult females caught in the Fremantle sardine fishery (2000 to 2005) (Table 1), which operates in inner shelf waters off Perth (Fig. 1). As samples were obtained from the commercial fishery, some months had more data than others. All months had between 25 and 600 samples, except January $(n=5)$.

Sardine eggs (including Day 1 and Day 2 eggs) were sampled using a grid of winter (July or August) plankton sampling stations as part of daily egg production method surveys completed by the Department of Fisheries, Western Australia (DFWA) (D. Gaughan unpubl. data). Stations were located between Two Rocks and Cape Leeuwin from inshore waters to the shelf break (300 to $500 \mathrm{~m}$ deep). Eggs were collected from vertical bongo net tows (net $0.26 \mathrm{~m}$ diameter, $300 \mu \mathrm{m}$ mesh). Concentrations of eggs and larvae from all plankton samples incorporated into this study, were expressed as no. $\mathrm{m}^{-3}$ of seawater sampled using volumes calculated from General Oceanics flowmeters fitted to each net. Sardine egg concentrations were overlain on the monthly mean sea surface temperature plots of the study region (data obtained from Aqua-MODIS, NASA).

Sardine eggs $<24 \mathrm{~h}$ old were also counted in monthly plankton samples (1996 to 1998) (Table 1) along the Hillarys transect (see Pearce et al. 2006) (Fig. 1). Vertical tows were taken every $5 \mathrm{~km}$ with a bongo net $(0.26 \mathrm{~m}$ diameter, $300 \mu \mathrm{m}$ mesh) to $70 \mathrm{~m}$ depth, or to within $3 \mathrm{~m}$ of the bottom in shallower water. Because of rough sea conditions, some stations were omitted in March and August 1998, and no samples were taken in February 1997.

Larval fish. Yolk-sac, pre-flexion and post-flexion sardine larvae were removed from all vertical bongo net tows (see above) and from oblique plankton samples taken along the Two Rocks transect between August 2002 and December 2004 (Table 1). All stations (Stns A-E) were sampled on a quarterly basis and, in addition, the 3 inshore stations (Stns A-C) were sampled monthly, when possible (see Muhling et al. 2008). Plankton samples on the Two Rocks transect were taken with daytime oblique bongo net tows to $150 \mathrm{~m}$ depth, or to just above the bottom in shallower water (Muhling et al. 2008). Nets were fitted with 100 and $355 \mu \mathrm{m}$ mesh (mouth area $0.196 \mathrm{~m}^{2}$, diameter $0.6 \mathrm{~m}$ ) and were towed at about 2 knots. Only larvae from the $355 \mu \mathrm{m}$ mesh were used. Plankton samples from the DFWA grid and Hillarys transect were preserved in borax-buffered $5 \%$ formalin, while samples from the Two Rocks transect were split, with one subsample preserved in $10 \%$ buffered formalin and the other in $100 \%$ ethanol.

Data on the distribution and abundance of sardine eggs and larvae were thus available from 2 snapshots over a broad sampling grid (DFWA samples), and from more regular samples on a more restricted spatial scale (Hillarys and Two Rocks transect samples).

Length and growth rate of sardine larvae. The standard notochordal lengths (SL) of sardine larvae collected at each station on each cruise along the Two Rocks transect were measured to $0.1 \mathrm{~mm}$ accuracy using an eyepiece micrometer. Where $>50$ larvae were collected in any tow, a sub-sample of 50 randomly selected specimens was measured. Neuston net samples taken on quarterly cruises along the Two Rocks transect ( $1 \mathrm{~m}^{2}$ square net, $1 \mathrm{~mm}$ mesh) provided larger sardine larvae (>8 $\mathrm{mm}$ length) for growth analyses only.

Sixty-eight sardine larvae from 9 bongo net samples (ethanol-preserved subsamples) and 2 neuston net samples from the Two Rocks transect were aged using daily growth rings in sagittal otoliths. The SL of each larva used for otolith analysis was measured to the nearest $0.05 \mathrm{~mm}$ using Leica IM1000 image software. The sagittal otoliths were removed from each larva, cleaned, air dried and mounted in cosmetic nail polish on microscope slides. The best condition otolith from each larva was photographed at varying foci using a JVC TK-C1381 camera with transmitted light under an Olympus SZX12 compound microscope. Each consecutive pair of adjacent light and dark growth zones was assumed to correspond to daily growth zones (validated for this species by Hayashi et al. 1989). The daily growth zones for all larvae were counted on 2 separate occasions and without prior knowledge of standard lengths. Where the 2 counts disagreed, a third count was made. If all 3 counts differed, the age information for the fish was not included in age analyses. As deposition of the initial increment for sardine larvae occurs 2.5 to $3.0 \mathrm{~d}$ after hatching (Hayashi et al. 1989), $2 \mathrm{~d}$ were added to all counts so that post-hatch age could be estimated.

The relationship between SL and larval age (d) was examined and described using the Laird-Gompertz growth curve:

$$
L_{t}=L_{0} e^{\left(g_{0} / \alpha\right)\left(1-\mathrm{e}^{\alpha t}\right)}
$$

where $L_{t}$ is the length at age $t_{1} L_{0}$ is the length at hatching $(t=0), g_{0}$ is the specific growth rate at hatching and $\alpha$ is the rate of exponential decay of the specific growth 
rate. The parameters were estimated by maximising the log-likelihood in Excel software. The Laird-Gompertz growth curve provides a significantly better fit to the lengths at age of sardine larvae than a linear curve (likelihood ratio test, $\mathrm{p}<0.01$, Cerrato 1990). Our use of this growth model also enabled direct comparison with the results of the sardine growth study by Gaughan et al. (2001b). The likelihood ratio test was also used to determine whether Laird-Gompertz growth curves fitted separately to length-at-age data for sardine larvae collected during the warmer austral summer (November to April) differed significantly from those for larval sardines collected over the cooler winter period (May to October).

The average daily growth rates $\left(\mathrm{mm} \mathrm{d}^{-1}\right)$ of sardine larvae between 3 and $18 \mathrm{~d}$ old from the lower west coast were compared with estimates for these ages of fish (same species) in southern Australia (118 to $\left.137^{\circ} \mathrm{E}\right)$ using data in Gaughan et al. (2001b). The predicted lengths at each age were then calculated using Laird-Gompertz equations for the 2 regions. The average daily growth rates were determined by averaging the differences in predicted lengths between each of the successive ages. The associated 95\% confidence intervals for each of the 2 mean values were determined using a likelihood profile approach (Hilborn \& Mangel 1997).

\section{RESULTS}

\section{Seasonal cycles of oceanographic and biological variables}

The seasonal maxima of surface chl a and Fremantle mean sea level (FMSL, as a proxy for Leeuwin Current strength) were evident during late austral autumn and winter (May to August) (Fig. 2). Strong Leeuwin Current flow was associated with higher surface chlorophyll, although there was a 1 to 2 mo lag between the 2 variables in some years, with FMSL peaking before chlorophyll. In contrast, southerly wind stress was highest during summer (November to March). Southerly wind stress and surface chlorophyll concentration were inversely correlated $\left(\mathrm{R}^{2}=0.70\right)$ (Fig. 2). Maximum SST across the Two Rocks transect (2002 to 2004) occurred in late summer (February to March), and

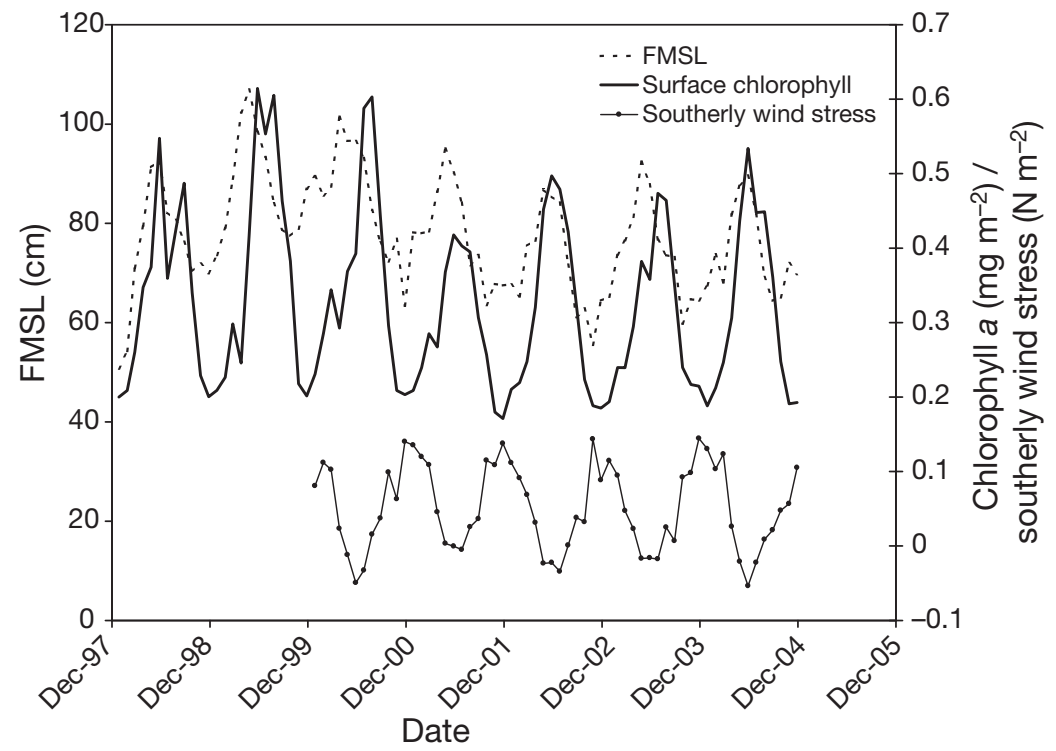

Fig. 2. Fremantle mean sea level (FMSL) and surface chlorophyll concentration (1998 to 2005)

minimum values were in late winter (August to October) (Fig. 3). The surface chlorophyll cycle lagged the maximum SST signal by 3 to 5 mo. Throughout the study area, high SST and strong southerly winds in summer were followed by increased Leeuwin Current flow and surface chlorophyll concentration through autumn and winter.

\section{Sardine spawning cycles}

The mean monthly GSI for adult sardines sampled from the Fremantle fishery (2000 to 2005) peaked in win-

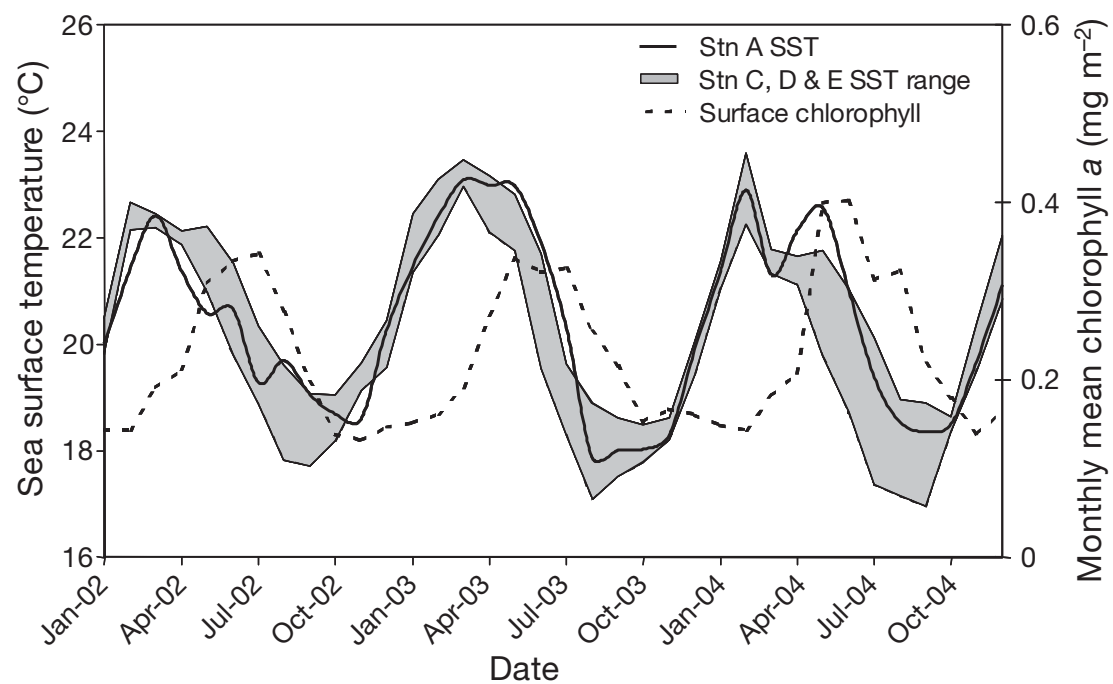

Fig. 3. Remotely sensed sea surface temperature (SST) and surface chlorophyll concentration (2002 to 2004) across the Two Rocks transect. Monthly SST at Stn A, and the range of temperatures across Stns C, D and E, are shown. See Fig. 1b for station locations 


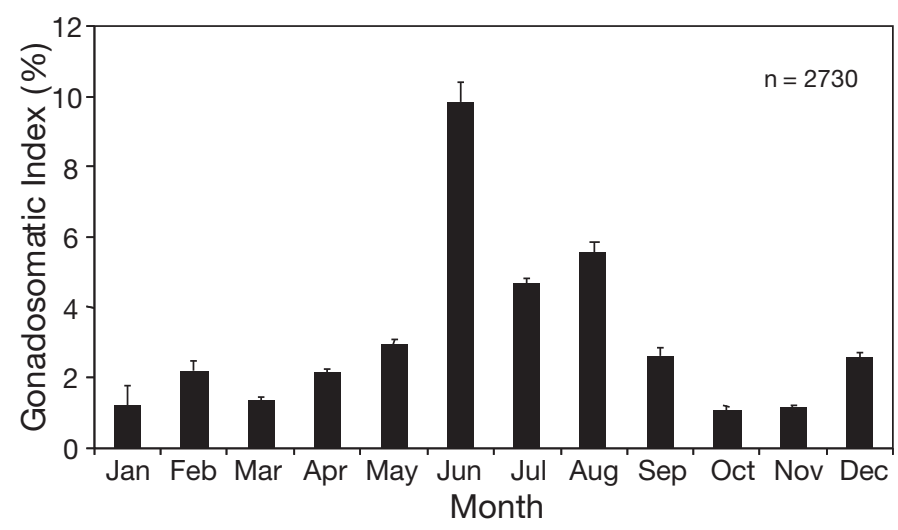

Fig. 4. Mean monthly gonadosomatic index of adult sardines caught by the Fremantle fishery in the Perth region (2000 to 2005). Means + SE

ter, especially in June, and was at a minimum in October and November (Fig. 4). Sardine egg concentrations across the Hillarys transect, however, were highest during summer (December to January) and winter (May to September), with lower concentrations in spring (Fig. 5). Variability in sardine egg concentrations was high between the 2 years of sampling (1997 and 1998).

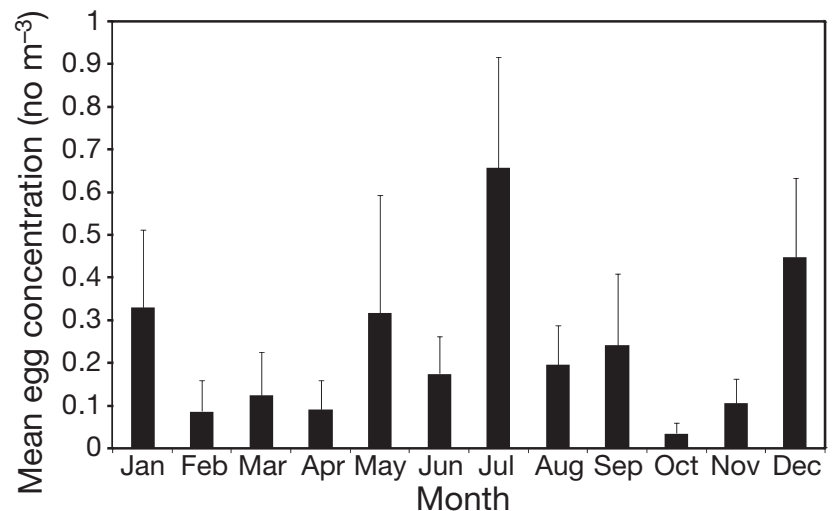

Fig. 5. Mean monthly concentrations of Day 1 sardine eggs $[\ln (x+1)$ transformed] across the Hillarys transect (1997-1998). Means +SE for all 6 stations (see Fig. 1b) between 15 and $40 \mathrm{~km}$ from shore. Some stations were omitted in March and August 1998, and no samples were taken in February 1997. See Fig. 1b for location of Hillarys transect

Sardine eggs were widespread between Two Rocks and Cape Naturaliste in the winters of 2002 and 2004 (Fig. 6). During 2004, egg and larval concentrations were highest and eggs were found at more stations throughout the study area. Where sampling extended

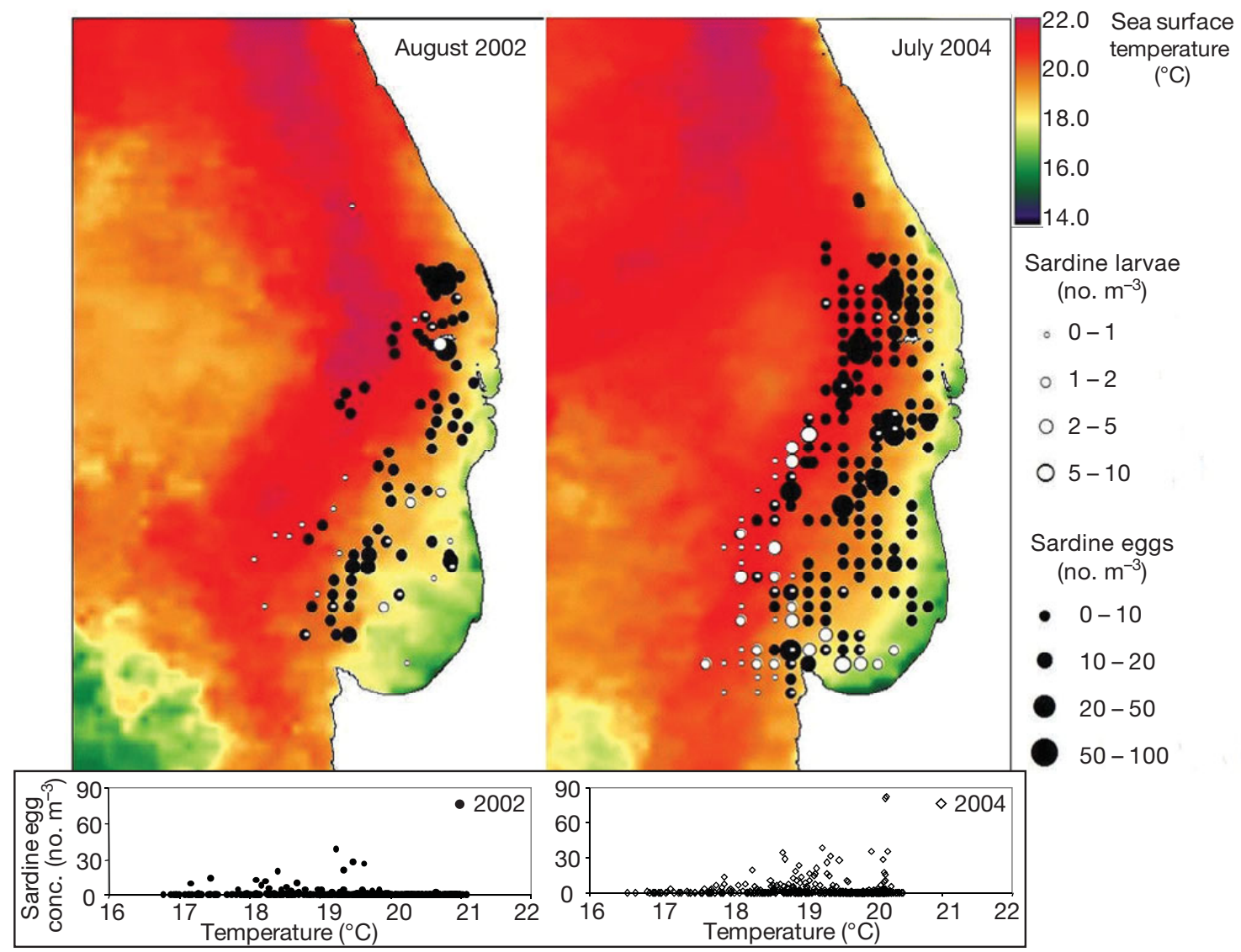

Fig. 6. Sardine egg and larval concentrations between Two Rocks and Cape Naturaliste (winter 2002 and 2004). Satellite-derived sea surface temperatures shown 


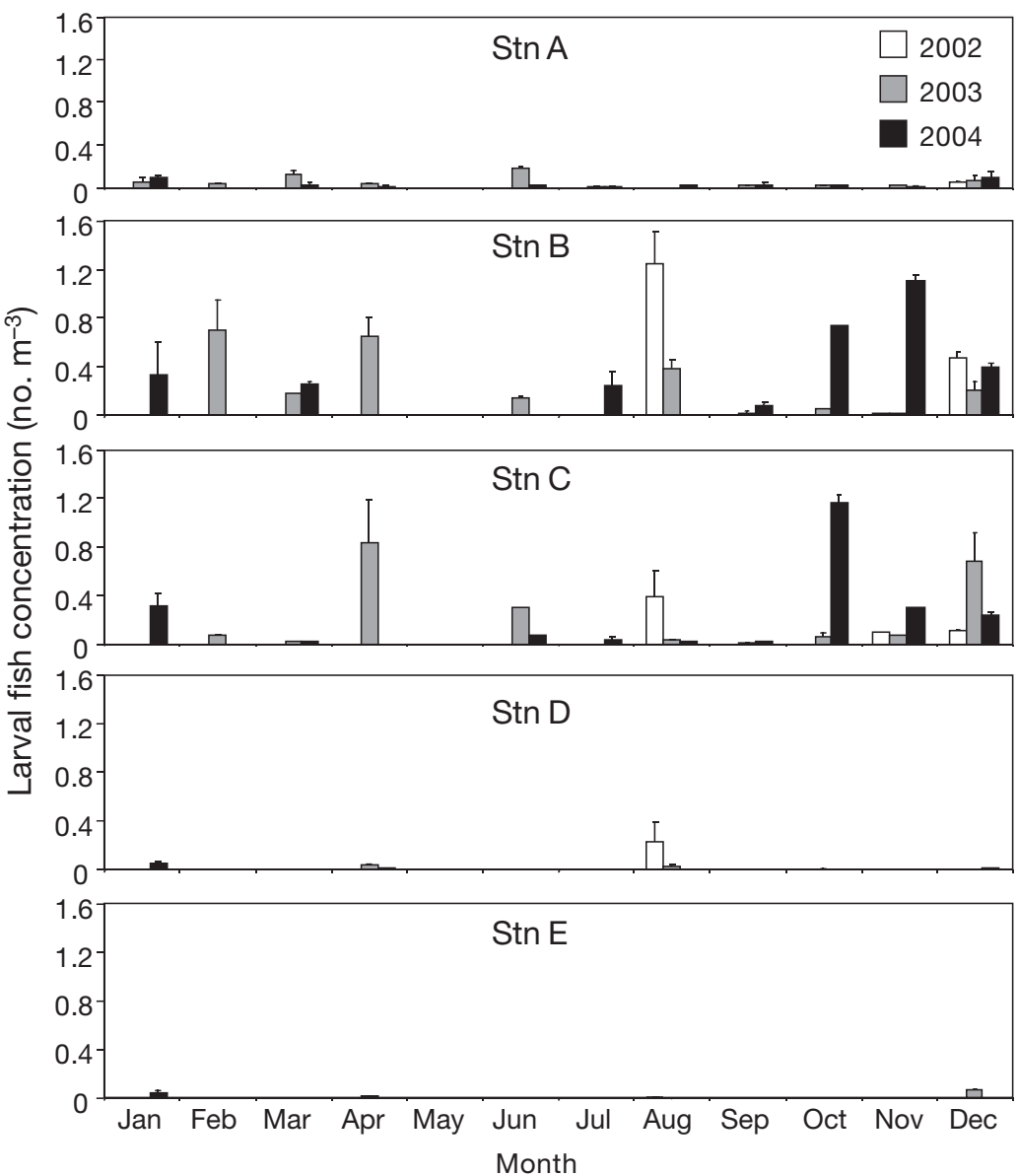

Fig. 7. Concentration (means $+\mathrm{SE}$ ) of sardine larvae at Stns A to E on the Two Rocks transect (August 2002 to December 2004). See Fig. 1b for station locations south of Cape Naturaliste, both eggs and larvae were rare.

The majority of sardine eggs and larvae were recorded within water of Leeuwin Current origin (Fig. 6). Warm water derived from the Leeuwin Current was located closer to the coast around Geographe Bay (north of Cape Naturaliste) in 2004 than in 2002, and this corresponded to a more nearshore distribution of sardine eggs (Fig. 6). Comparison of the extracted mean monthly sea surface temperature and sardine egg concentrations for each sampled station revealed that sardine eggs were found in sea surface temperatures of 17 to $20.5^{\circ} \mathrm{C}$. Highest egg concentrations were found at stations where the sea surface temperature was 18 to $20^{\circ} \mathrm{C}$, i.e. within water of Leeuwin Current origin (Fig. 6).

Sardine larvae were common yearround across the Two Rocks transect (between August 2002 and December 2004, Fig. 7). Highest larval concentrations (0.5 to $1.2 \mathrm{~m}^{-3}$ ) generally occurred on the continental shelf (Stns $\mathrm{B}$ and $\mathrm{C}$ ). Larval concentrations were often highly variable between years (e.g. see August and October).

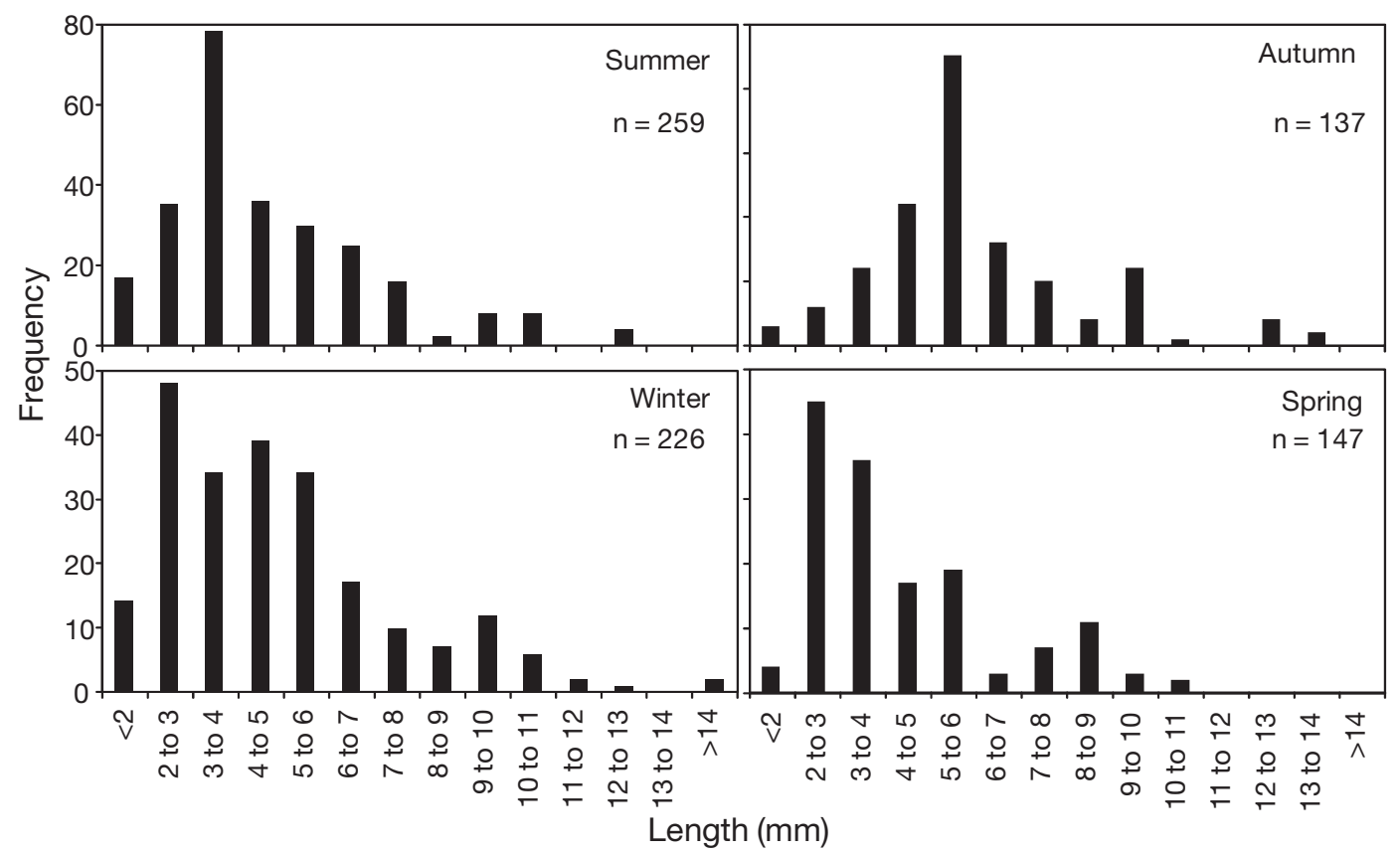

Fig. 8. Length frequency distributions of sardine larvae at Stns B (40 m) and C (100 m) on the Two Rocks transect (August 2002 to December 2004) by season. See Fig. 1 b for station locations 


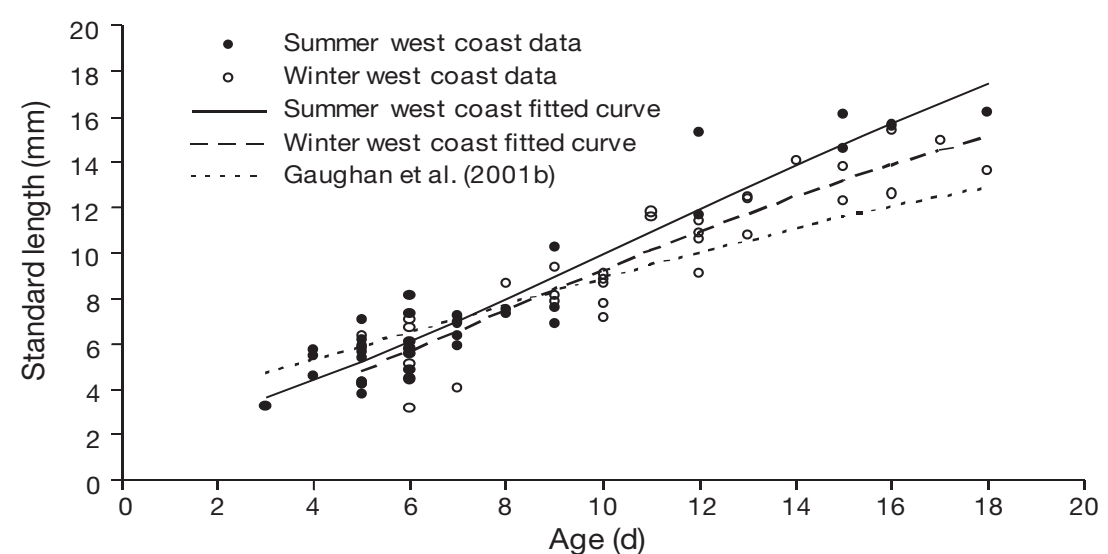

Fig. 9. Observed data and Laird-Gompertz growth curves fitted to lengths at age of larval sardines ( 3 to $18 \mathrm{~d}$ post hatch) from the west coast of Western Australia (Two Rocks transect, Fig. 1b) during winter and summer. The Laird-Gompertz growth curve for sardine larvae of the same age range from the south coast of Western Australia is also included

(Gaughan et al. 2001b)

\section{Larval sardine lengths and growth rates}

Most sardine larvae caught at Stns B and C were 2 to $8 \mathrm{~mm}$ SL (Fig. 8), and small sardine larvae were recorded throughout all seasons.

The Laird-Gompertz growth curves fitted to the lengths at age of larval sardines collected over the summer and winter periods, i.e. November to April ( $\mathrm{n}=$ 35) and May to October $(n=33)$, respectively, were significantly different $(\mathrm{p}<0.05)$. The average daily growth rate of larval sardines was slightly higher $\left(0.92 \mathrm{~mm} \mathrm{~d}^{-1}\right)$ in summer than in winter $\left(0.78 \mathrm{~mm} \mathrm{~d}^{-1}\right)$.

The likelihood ratio test indicated that the LairdGompertz growth curve for all larval sardine lengths at age estimated in this study (average daily growth rate $\left.=0.82 \mathrm{~mm} \mathrm{~d}^{-1}\right)$ was significantly different $(\mathrm{p}<$ 0.01) from that recorded by Gaughan et al. (2001b) for sardine larvae of comparable ages from the south coast of Western Australia (average daily growth rate $=0.55 \mathrm{~mm} \mathrm{~d}^{-1}$ ) (Fig. 9). Estimates of the LairdGompertz growth parameters, $L_{0}, g_{0}$ and $\alpha$ for the pooled length-at-age data for the summer and winter periods on the west coast of Western Australia were $3.35 \mathrm{~mm}, 0.25 \mathrm{~d}^{-1}$ and $0.129 \mathrm{~d}^{-1}$, respectively; for the south coast of Western Australia, these parameters were $1.91 \mathrm{~mm}, 0.25 \mathrm{~d}^{-1}$ and $0.10 \mathrm{~d}^{-1}$, respectively.

\section{DISCUSSION}

\section{Spatial and temporal patterns of sardine spawning}

Sardinops sagax spawns in shelf waters at different times in different geographical locations (Ward et al. 2003). Eggs and larvae are most abundant along the south and west coasts of Western Australia from June to August and from December to February (Gaughan et al. 1990, Fletcher et al. 1994). This is in contrast to the pattern off South Australia, where the main sardine spawning season in summer and autumn is associated with coastal upwelling, increased primary production and higher zooplankton biomass (Ward et al. 2006). Favourable feeding and growth conditions for larvae therefore occur in conjunction with potentially favourable larval retention conditions. GSI data suggest that spawning off southwestern Australia peaks, instead, at a time of strong southward Leeuwin Current flow (June to August) with no upwelling. Primary productivity in the study region is greatest during this time, coincident with enhanced vertical mixing. However, given the spawning locations of sardine (suggested by the winter egg and larval surveys) between Two Rocks and Cape Naturaliste and the strong Leeuwin Current flow along the shelf in June and July (as indicated by FMSL data), it is probable that eggs and larvae resulting from mid-winter spawning events are subjected to strong southward advection (Caputi et al. 1996). While onshore Ekman transport associated with the passage of cold front systems in winter may slightly improve retention of eggs and larvae and result in some interannual recruitment variability, the monthly scale of sampling in this study made the influence of such events difficult to discern.

Overall concentrations of sardine larvae in the present study were not particularly low by regional and global standards. Across the Two Rocks transect, mean larval sardine concentrations up to $1.2 \mathrm{~m}^{-3}$ were found, while at some southern stations on the winter sampling grid in 2004, larval concentrations $>2 \mathrm{~m}^{-3}$ were frequently found. Concentrations of larvae on the Two Rocks transect were comparable to or higher than those found near Albany on the south coast of Western Australia (Fletcher \& Tregonning 1992, Fletcher 1999), those measured by Beckley \& Hewitson (1994) off southeastern Africa, and those on the open shelf off South Australia (Ward et al. 2006). Concentrations of larvae found at winter sampling grid stations in this study were comparable to those in the more protected waters of Spencer Gulf, around Kangaroo Island (Ward et al. 2006), to concentrations in the Benguela Current ecosystem (Huggett et al. 1998, Stevenik et al. 2001), and to concentrations of Sardina pilchardus in the northwestern Mediterranean (Olivar et al. 2001).

However, when compared to the sardine GSI data (from the Fremantle fishery), egg and larval concentrations (from the Hillarys and Two Rocks transects) were 
higher than expected in summer (given the comparatively low spawning activity), and lower than expected in winter. Spawning activity during summer may not be as high as in winter, but it is likely that eggs and larvae are better retained over the shelf in summer due to the presence of the Capes Current, a wind-induced countercurrent that flows sporadically northward over the midshelf (Gersbach et al. 1999, Pearce \& Pattiaratchi 1999). Some offshore Ekman transport may be present in summer, especially at the surface (Muhling \& Beckley 2007), but we postulate that retention conditions during summer would still be more advantageous than during winter. It is therefore possible that a comparatively small proportion of the sardine spawning period could contribute the majority of the year's recruits to the adult population on the lower west coast of Western Australia.

\section{Implications for fisheries}

Low commercial catches of clupeiform fishes off southwestern Australia may be partially explained by the oligotrophic status of the waters (Hanson et al. 2005) with consequently lowered secondary production (Koslow et al. 2006), and, therefore, a reduced food supply for pelagic larvae. However, this effect is likely compounded by the fact that the time of greatest primary productivity off the southwestern Australian coast (autumn/winter) (Lourey et al. 2006) occurs at a time of potentially unfavourable southward transport for shelf spawning species. Clupeiod larvae are generally poor swimmers compared to other teleost larvae (Fisher et al. 2005); their reproductive strategy instead focuses on spawning throughout the year, so that larvae hatched during times of favourable retention may survive (Hutchings et al. 2002).

Current velocities within the Leeuwin Current during autumn and winter regularly exceed 1 knot (Smith et al. 1991), producing a potential southward transport of larvae within the current of more than $40 \mathrm{~km} \mathrm{~d}^{-1}$ (assuming passive transport), or $20 \mathrm{~km} \mathrm{~d}^{-1}$ inshore of the main current as it extends inshore over the shelf (Caputi et al. 1996), with no apparent mechanism for larval retention close to spawning areas on the open continental shelf. The existence of apparently separate sardine stocks between the west and south coasts of Western Australia (Gaughan et al. 2001c) suggests that larvae entrained within the Leeuwin Current are not usually recruited to south coast stocks. However, young $(<2$ yr) sardines are reportedly common in the comparatively protected waters of Geographe Bay, north of Cape Naturaliste $\left(32^{\circ} 31^{\prime} \mathrm{S}\right.$ to $33^{\circ} 32^{\prime} \mathrm{S}$, see Fig 1) (Gaughan et al. 2001c). Dispersal of larvae spawned on the open shelf around Two Rocks and Perth to Geographe Bay is therefore possible.
Bakun (1996) proposed 3 major classes of physical processes that characterise favourable reproductive habitats for coastal pelagic fishes: enrichment processes (e.g. upwelling), concentration processes (e.g. fronts and stable water columns), and retention mechanisms. All 3 mechanisms are largely absent from southwestern Australian waters. There are no largescale upwellings, few concentration processes, usually no strong hydrographic fronts, and no retention mechanisms for pelagic, shelf-spawned larvae during times of higher productivity (autumn and winter). A combination of these factors may be responsible for the low clupeiform stock sizes and catches off southwestern Australia.

The hypothesis that small sizes of clupeiod stocks and fisheries off southwestern Australia are largely related to advective processes, rather than to food limitation alone, is supported by our determination of larval sardine growth rates. Although larval sardine growth rates are highly variable worldwide, growth rates of sardine larvae from the Two Rocks transect were comparable to, or higher than, growth of similarly aged larvae from other more productive parts of the world (Castillo et al. 1985, Butler 1987). The surprisingly high growth rates of larval sardines in the current study may have resulted from warm water temperatures provided by the Leeuwin Current. After food availability, water temperature is the major determining factor for larval growth rate, as larvae typically grow faster with increasing temperature up to an optimum level, above which growth declines (Oozeki \& Watanabe 2000). Few published data exist on seasonal patterns of secondary production and biomass in the region studied; however, existing data suggest that maxima, if present, are in autumn/winter, similar to patterns of chlorophyll biomass (Koslow et al. 2006). There is thus no reason at present to suspect that high larval growth rates are supported by secondary production peaks at other times of year.

The effect of deleterious advection processes on sardine populations has also been noted on the Agulhas Bank, and in the Benguela Current system off southern Africa, where, despite high primary productivity, yields of pelagic fishes are lower than in the Humboldt system off South America. This may be due in part to the poor retention conditions for pelagic larvae along the southern African coast, as a result of the strong western boundary current (Agulhas Current) and the strong upwelling environment present off the west coast (Benguela system), which together may result in considerable offshore losses of pelagic eggs and larvae (Hutchings et al. 1998, 2002).

Overall, sardine eggs and larvae were found across the continental shelf between Two Rocks and Cape Naturaliste, and monthly transect data suggest spawn- 
ing activity throughout the year. However, while GSI data suggest a winter spawning peak, egg and larval concentrations were lower than expected in winter and were higher in summer. As most sardine eggs and larvae were sampled within the southward flowing Leeuwin Current, which is strongest during winter, this discrepancy may result from the significant southward advection of eggs and larvae during this time. The low stock sizes and fisheries for sardine and other clupeiod species off southwestern Australia may be due to a combination of low primary productivity (because of the suppression of large-scale upwelling by the Leeuwin Current) compounded by a modest seasonal maximum in primary productivity during the time of least favourable retention for pelagic larvae (i.e. winter). The relatively high growth rates of sardine larvae from the study area (by world standards) support the notion that clupeiod fish populations are controlled by a combination of advective processes in conjunction with primary productivity patterns, rather than simply by a scarcity of food for pelagic larvae.

Acknowledgements. The Western Australian Strategic Research Fund for the Marine Environment and Murdoch University funded part of this research and provided a PhD scholarship for B.A.M. N. Mortimer, J. Strzelecki and T. Koslow are thanked for coordinating sample collection on the Two Rocks transect and for help with data interpretation. The Western Australian Department of Fisheries is acknowledged for sardine GSI, egg and larval sample collection and data processing. The National Tidal Centre, the Australian Bureau of Meteorology and DISC(NASA) provided oceanographic and remotely sensed data, and A. Pearce and P. Fearns helped with processing and interpretation of these data. M. Harvey is thanked for help with GIS analyses.

\section{LITERATURE CITED}

Bailey KM, Houde ED (1989) Predation on eggs and larvae of marine fishes and the recruitment problem. Adv Mar Biol 25:1-83

Bakun A (1996) Patterns in the ocean: ocean processes and marine population dynamics. California Sea Grant College System, University of California, La Jolla, CA

Beckley LE, Hewitson JD (1994) Distribution and abundance of clupeiod larvae along the east coast of South Africa in 1990/91. S Afr J Mar Sci 14:205-212

> Beckley LE, van der Lingen C (1999) Biology, fishery and management of sardines (Sardinops sagax) in southern African waters. Mar Freshw Res 50:955-978

Butler JL (1987) Comparison of the early life history parameters of Pacific sardine and northern anchovy with implications of species interactions. PhD thesis, University of California, San Diego, CA

Caputi N, Fletcher WJ, Pearce AF, Chubb CF (1996) Effect of the Leeuwin Current on the recruitment of fish and invertebrates along the Western Australian coast. Mar Freshw Res 47:147-155

Castillo G, Aguilera G, Herrera G, Bernal PA and others (1985) Larval growth rates of Pacific sardine Sardinops sagax off central Chile, determined by count of daily rings in otoliths. Biol Pesq 14:3-10

Cerrato RM (1990) Interpretable statistical tests for growth comparisons using parameters in the von Bertalanffy equation. Can J Fish Aquat Sci 47:1416-1426

Cole J (1999) Environmental conditions, satellite imagery, and clupeoid recruitment in the northern Benguela upwelling system. Fish Oceanogr 8:25-38

DeVlamming V, Grossman G, Chapman F (1982) On the use of the gonadosomatic index. Comp Biochem Physiol 73: 31-39

Fearns PR, Twomey L, Zakiyah U, Helleren S, Vincent W, Lynch MJ (2007) The Hillarys Transect (3): optical and chlorophyll relationships across the continental shelf off Perth. Cont Shelf Res 27:1719-1746

Feng M, Meyers G, Pearce A, Wijffels S (2003) Annual and interannual variations of the Leeuwin Current at $32^{\circ} \mathrm{S}$. J Geophys Res 108, doi:10.1029/2002JC001763

Fisher R, Leis JM, Clark DL, Wilson SK (2005) Critical swimming speeds of late-stage coral reef fish larvae: variation within species, amongst species and between locations. Mar Biol 147:1201-1212

> Fletcher WJ (1999) Vertical distribution of pilchard (Sardinops sagax) eggs and larvae off Southern Australia. Mar Freshw Res 50:117-122

Fletcher WJ, Tregonning RJ (1992) Distribution and timing of spawning by the Australian pilchard (Sardinops sagax neopilchardus) off Albany, Western Australia. Aust J Mar Freshw Res 43:1437-1449

- Fletcher WJ, Tregonning RJ, Sant GJ (1994) Interseasonal variation in the transport of pilchard eggs and larvae off southern Western Australia. Mar Ecol Prog Ser 111: 209-224

Funes-Rodriguez R, Hinojosa-Medina A, Avendano-Ibarra R, Hernandez-Rivas M, Saldierna-Martinez R, Watson W (2001) Spawning of small pelagic fishes in Bahia Magdalena Baja California Sur, Mexico, at the beginning of the 1997-1998 El Niño. Estuar Coast Shelf Sci 53:653-664

> Gaughan DJ, Neira FJ, Beckley LE, Potter IC (1990) Composition, seasonality and distribution of the ichthyoplankton in the lower Swan Estuary, south-western Australia. Aust J Mar Freshw Res 41:529-543

> Gaughan DJ, White KV, Fletcher WJ (2001a) The links between functionally distinct adult assemblages of Sardinops sagax: larval advection across management boundaries. ICES J Mar Sci 58:597-606

Gaughan DJ, Fletcher WJ, White KV (2001b) Growth rate of larval Sardinops sagax from ecosystems with different levels of productivity. Mar Biol 139:831-837

Gaughan DJ, Baudains GA, Mitchell RWD, Leary TI (2001c) Pilchard (Sardinops sagax) nursery areas and recruitment process assessment between different regions in southern Western Australia. Fisheries, Research Report 131, Department of Fisheries, Perth, Western Australia

- Gersbach GH, Pattiaratchi C, Ivey GN, Cresswell GR (1999) Upwelling on the south-west coast of Australia - source of the Capes Current? Cont Shelf Res 19:363-400

Hanson CE, Pattiaratchi C, Waite AM (2005) Seasonal production regimes of south-western Australia: influence of the Capes and Leeuwin Currents on phytoplankton dynamics. Mar Freshw Res 56:1011-1026

Hayashi A, Yamashita Y, Kawaguchi K, Ishii T (1989) Rearing method and daily otolith ring of Japanese sardine larvae. Nippon Suisan Gakkai 55:997-1000

Hilborn R, Mangel M (1997) The ecological detective: confronting models with data. Princeton University Press, Princeton, NJ 
Huggett JA, Boyd AJ, Hutchings L, Kemp A (1998) Weekly variability of clupeoid eggs and larvae in the Benguela jet current: implications for recruitment. S Afr J Mar Sci 19:197-210

Hutchings L, Barange M, Bloomer SF, Boyd AJ and others (1998) Multiple factors affecting South African anchovy recruitment in the spawning transport and nursery areas. S Afr J Mar Sci 19:211-225

Hutchings L, Beckley LE, Griffiths MH, Roberts MJ, Sundby $S$, van der Lingen C (2002) Spawning on the edge: spawning grounds and nursery areas around the southern African coastline. Mar Freshw Res 53:307-318

Hutchins B, Thompson M (2001) Marine and estuarine fishes of south-western Australia: a field guide for anglers and divers. Western Australian Museum, Perth

Koslow JA, Pearce AF, Mortimer N, Strzelecki J and others (2006) Biophysical oceanography off Western Australia: biological communities, pattern, process, and ecosystem dynamics across the continental shelf and slope. In: Keesing JK, Heine JN (eds) Strategic Research Fund for the Marine Environment Final Report, Vol 1. The SRFME initiative and collaborative linkages program. Strategic Research Fund for the Marine Environment, CSIRO, Perth, p 143-213

Lasker R, Smith PE (1976) Estimation of the effects of environmental variations on the eggs and larvae of the northern anchovy. CCOFI Rep 19:128-137

Lourey MJ, Dunn JR, Waring J (2006) A mixed-layer climatology of Leeuwin Current and Western Australian shelf waters: seasonal nutrient dynamics and biomass. J Mar Syst 59:25-51

Muhling BA, Beckley LE (2007) Seasonal variation in horizontal and vertical structure of larval fish assemblages off south-western Australia, with implications for larval transport. J Plankton Res 29:967-983

Muhling BA, Beckley LE, Koslow JA, Pearce AF (2008) Larval fish assemblages and water mass structure off the oligotrophic south-western Australian coast. Fish Oceanogr $17: 16-31$

Olivar MP, Salat J, Palomera I (2001) Comparative study of spatial distribution patterns of early stages of anchovy and pilchard in the NW Mediterranean Sea. Mar Ecol Prog Ser 217:111-120

Oozeki Y, Watanabe Y (2000) Comparison of somatic growth and otolith increment growth in laboratory-reared larvae of Pacific saury, Cololabis saira, under different tempera-

Editorial responsibility: Matthias Seaman, Oldendorf/Luhe, Germany ture conditions. Mar Biol 136:349-359

Pearce AF, Pattiaratchi C (1999) The Capes Current: a summer countercurrent flowing past Cape Leeuwin and Cape Naturaliste, Western Australia. Cont Shelf Res 19:401-420

Pearce AF, Lynch MJ, Hanson CE (2006) The Hillarys transect (1): seasonal and cross-shelf variability of physical and chemical water properties off Perth, Western Australia, 1996-98. Cont Shelf Res 26:1689-1729

Sanchez-Velaso L, Avalos-Garcia C, Renteria-Cano M, Shirasago B (2004) Fish larvae abundance and distribution in the central Gulf of California during strong environmental changes (1997-1998 El Niño and 1998-1999 La Niña). Deep-Sea Res 51:711-722

Schwartzlose RA, Alheit J, Bakun A, Baumgartner TR and others (1999) Worldwide large-scale fluctuations of sardine and anchovy populations. S Afr J Mar Sci 21:289-348

Smith PE, Moser HG (2003) Long-term trends and variability in the larvae of Pacific sardine and associated fish species of the California Current Region. Deep-Sea Res 50: $2519-2536$

Smith RL, Huyer A, Godfrey JS, Church JA (1991) The Leeuwin Current off Western Australia, 1986-87. J Phys Oceanogr 21:323-345

Somarakis S, Ganias K, Siapatis A, Koutsikopoulos C, Machias A, Papaconstantinou C (2006) Spawning habitat and daily egg production of sardine (Sardina pilchardus) in the eastern Mediterranean. Fish Oceanogr 15:281-292

Stevenik EK, Sundby S, Cloete R (2001) Influence of buoyancy and vertical distribution of sardine Sardinops sagax eggs and larvae on their transport in the northern Benguela ecosystem. S Afr J Mar Sci 23:85-98

Thomas AC, Strub TP, Carr ME, Weatherbee R (2004) Comparisons of chlorophyll variability between the four major global eastern boundary currents. Int J Remote Sens 25: 1443-1447

- Ward TM, Staunton-Smith J, Hoyle S, Halliday IA (2003) Spawning patterns of four species of predominantly temperate pelagic fishes in the sub-tropical waters of southern Queensland. Estuar Coast Shelf Sci 56:1125-1140

Ward TM, McLeay LJ, Dimmlich WF, Rogers PJ and others (2006) Pelagic ecology of a northern boundary current system: effects of upwelling on the production and distribution of sardine (Sardinops sagax), anchovy (Engraulis australis) and southern bluefin tuna (Thunnus maccoyii) in the Great Australian Bight. Fish Oceanogr 15:191-207

Submitted: January 4, 2007; Accepted: March 13, 2008

Proofs received from author(s): July 3, 2008 